\title{
Значение генов устойчивости к засухе в условиях Южной лесостепи Омской области
}

Шепелев С.С. ${ }^{1}$ *, к.с.-х.н., зав. лаб.; Шаманин В.П. ${ }^{1}$, д.с.-х.н., профессор; Потоикая И.В. ${ }^{l}$, к.с.-х.н., дочент; Чурсин А.C. ${ }^{1}$, зав. лаб.; Пожерукова В.E. ${ }^{l}$, к.б.н., н.с.; Гладких М.С. ${ }^{1}$, к.с.-х.н., н.с.; Моргунов А.И. ${ }^{2}$, к.с-х.н., адьюнкт-преподаватель.

${ }^{1}$ ФББОУ ВО Омский ГАУ, Омск, Россия;

${ }^{2}$ Университет штата Вашингтон, Пулман, США.

*e-mail: sergeyschepelew@mail.ru

Проведено фенотипирование и генотипирование яровой мягкой пшеницы, в условиях южной лесостепи Западной Сибири. Показана селекиионная цеенность линий с генами засухоустойчивости 1-feh w3 и TaDreb-B1 для повышения засухоустойчивости и урожайности сортов пшеницы.

Ключевые слова: яровая пшеница, засухоустойчивость, признаки продуктивности растения, КАSP-маркеры.

\section{Significance of drought tolerance genes under conditions of southern forest-steppe in Omsk region}

Shepelev S.S. ${ }^{l}, \quad$ Shamanin V.P. ${ }^{l}, \quad$ Pototskaya I.V. ${ }^{l}$, Chursin A.S. ${ }^{l}$, Pozherukova V.E. ${ }^{1}$, Gladkih M.S. ${ }^{1}$, Morgunov A.I. ${ }^{2}$

${ }^{1}$ Omsk State Agrarian University, Omsk, Russia;

${ }^{2}$ Washington State University, Pullman, USA.

Phenotyping and genotyping of spring bread wheat under conditions of southern forest-steppe of Western Siberia was carried out. There is shown the breeding value of lines with drought tolerance genes 1-feh w3 and TaDreb-B1 for increasing of yield and drought tolerance of wheat varieties.

Keywords: spring wheat, drought tolerance, productivity traits of plants, KASP-markers.

В связи с повышением средней минимальной и максимальной температуры воздуха в Омской области за последние 50 лет и в результате увеличения числа засушливых лет [1], стоит проблема повышения засухоустойчивости современных сортов [2]. В условиях Западной Сибири слабо изучены механизмы засухоустойчивости и генетическими источниками для повышения урожайности в условиях засухи могут служить сорта пшеницы с генами TaDreb-B1 [3] и 1-feh w3 [4]. Белки DREB представляют собой большое семейство транскрипционных факторов, обеспечивающих связывание РНКполимеразы с генами, контролирующими устойчивость к засухе, солевынос- 
ливость и холодостойкость [5]. К настоящему моменту получены два засухоустойчивых сорта-носители гена 1-feh w3: Kauz (аллель Т, Kauz type) сорт, характеризующийся высокой концентрацией запасных углеводов в стебле в условиях засухи и Westonia (аллель C, Westonia type) - сорт, характеризующийся низкой концентрацией запасных углеводов в стебле в условиях засухи [6].

Материал и методы исследований. В 2017-2018 гг. проведено фенотипирование коллекции яровой мягкой пшеницы, включающей лучшие реестровые сорта и перспективные линии отечественной и зарубежной селекции; линии гексаплоидной синтетической пшеницы; гибриды, полученные путем гибридизации сортов местной селекции и синтетической пшеницы. Всего изучено 150 сортообразцов в четырехкратной повторности. Весь селекционный материал генотипирован в LGCGenomics (Великобритания) с использованием KASP-маркеров, ассоциированных с генами устойчивости к засухе 1-feh w3 и TaDreb-B1. В 2019 г. в опыт дополнительно включены гибриды, полученные от скрещивания синтетической пшеницы с местными сортами и селекционный материал контрольного питомника и конкурсного сортооиспытания Омского ГАУ, всего изучено 408 сортообразцов. В 2017-2018 гг. рассчитаны эффекты генов по 30 признакам и в 2019 г. - по 31 признаку. Для расчета эффектов генов использовали программу R-statisticsв оболочке R-Studionо методу Welchttest [7]. Погодные условия в 2017 г. характеризовались засушливыми условиями вегетации в первый период развития растений, в 2018 г., напротив, отмечено большое количество осадков с мая по июнь.

Результаты исследований. Осуществлен анализ вклада эффекта генов 1-feh w3 и TaDreb-B1 в продуктивность растений. В 2017 г. в засушливых условиях выявлен достоверный вклад аллеля Т гена 1-feh w3 (Kauz type) в формирование параметров корневой системы (биомасса, ширина, длина, площадь корней, объем, диаметр корней, число корневых окончаний, корневых вилок и корневых перекрестков) и признаки листового аппарата (опушение листа, восковой налет, число листьев, длина листа и ширина листа).

В условиях засухи сортообразцы, в генотипе которых идентифицирован аллель С гена 1-feh w3 (Westonia type),формировали корневую систему большей длины, но с меньшим диаметром и объемом корней, имели длинный и тонкий лист со слабым опушением. Отмечен достоверный вклад аллеля С гена 1-feh w3 в урожайность и отдельные компоненты урожайности: в 2017 г. - массу зерна главного колоса 1,46 г против 1,35 г (достоверно при $\mathrm{p}=0,04)$, в 2018 г. - в массу зерна главного колоса 1,84 г против 1,69 г (достоверно при $\mathrm{p}=0,04)$, массу зерна растения 1,83 г против 1,65 г (достоверно при $\mathrm{p}=0,02$ ) и число зерен с растения 39,6 шт. против 36,6 шт. (достоверно при $\mathrm{p}=0,03)$. 
Дополнительно нами изучен вклад гена 1-feh $w 3$ в формирование параметров зерновки (площадь, длина, ширина, циркулярность), содержание белка и клейковины в зерне. У сортообразцов Westonia type в 2017 г. выявлен достоверный вклад гена 1-feh $w 3$ в формирование ширины зерновки - 3,43 мм против 3,35 мм (достоверно при $\mathrm{p}=0,006$ ); содержание белка в зерне $17,5 \%$ против $16,9 \%$ (достоверно при $\mathrm{p}=0,04)$; в 2018 г. - в содержание клейковины в зерне 31,7 \% против 30,5 \% (достоверно при р=0,04); ширину зерновки 3,95 мм, против 3,85 мм (достоверно при p=0,01); циркулярность зерновки 0,74 против 0,73 (достоверно при $\mathrm{p}=0,03$ ); содержание белка в зерне 16,5 \% против 15,9 \% (достоверно при $\mathrm{p}=0,01)$.

Необходимо отметить, что данный ген 1 -feh $w 3$ присутствует в сортах и линиях селекции Омского ГАУ: 40 \% Kauz typeи 60 \% Westonia type соответственно.

В 2019 г. для подтверждения полученных результатов и расширения выборки селекционного материала дополнительно изучено 258 сортообразцов. У сортообразцов Westonia type отмечено достоверное превышение отдельных компонентов продуктивности: числа зерен растения - на 3,24 шт., $(\mathrm{p}=0,0002)$, числа зерен главного колоса - на 1,92 шт., $(\mathrm{p}=0,0000001)$, массы зерна растения - на 0,13 г ( $\mathrm{p}=0,0008)$, массы зерна главного колоса - на 0,08 г $(\mathrm{p}=0,0004)$, урожайности - на $21 \Gamma / \mathrm{M}^{2}(\mathrm{p}=0,001)$.

Вклад гена TaDreb-B1 в 2017-2018 гг. был незначителен в продуктивность растений, в 2019 г. установлен достоверный положительный эффект данного гена увеличение числа зерен главного колоса - на 2,8 шт. $(\mathrm{p}=0,008)$ и урожайности - на 22,2 г/м2 $(\mathrm{p}=0,004)$. Количество сортообразцов, у которых идентифицирован ген TaDreb-B1 составило $37 \%$.

Таким образом, из изученного селекционного материала носителями «благоприятных аллелей» генов 1-feh w3 и TaDreb-B1 являются 9,8 \% сортообразцов, которые целесообразно использовать в качестве генетических источников для селекции на засухоустойчивость. Из 45 выделенных сортообразцов данное сочетание аллелей генов характерно для 8 сортов (таблица) и 37 линий.

Таблица - Список сортов с идентифицированными генами устойчивости к засухе 1-feh w3 и TaDreb-B1

\begin{tabular}{|c|c|c|}
\hline № п/п & Сорт & Происхождение \\
\hline 1 & RВ07 & США \\
\hline 2 & Norden & США \\
\hline 3 & Степная 259 & Казахстан \\
\hline 4 & Степная 254 & Казахстан \\
\hline 5 & Омская 36 & Россия, Омск \\
\hline 6 & Омская 35 & Россия, Омск \\
\hline 7 & Силантий & Россия, Омск \\
\hline 8 & Новосибирская 16 & Россия, Новосибирск \\
\hline
\end{tabular}


Использование в селекционных программах данных сортов позволит повысить продуктивность растений и расширить генетическое разнообразие сортов по устойчивости к засухе.

Благодарности: данное исследование проведено при финансовой поддержке РНФ (проект № 16-16-10005).

\section{Список литературы}

1. Проблема засухоустойчивости яровой мягкой пшеницы в Западной Сибири и современные экспресс-методы ее оценки в полевых условиях / В.П. Шаманин [и др.] // Вестник Новосибирского ГАУ. - 2016. - № 3. - С. 57-64.

2. Синтетическая гексаплоидная пшеница как исходный материал для селекции на засухоустойчивость в условиях Западной Сибири / И.В. Потоцкая [и др.] // Вестник Омского ГАУ. - 2019. - № 1 (33). - С. 38-46.

3. Characterization of TaDREB1 in wheat genotypes with different seed germination under osmotic stress / M. Liu [et al.] // Hereditas. - 2018. - V. 155 (1).

4. Stem carbohydrate dynamics and expression of genes involved in fructan accumulation and remobilization during grain growth in wheat (Triticum aestivum L.) genotypes with contrasting tolerance to water stress / A. Yáñez [et al.] // PLoS One. - 2017. - V. 12 (5).

5. Liu Q, Kasuga M, Sakuma Y, Abe H, Miura S, Yamaguchishinozaki K, Shinozaki $\mathrm{K}$. Two transcription factors, dreb1 and dreb2, with an erebp/ap2 dna binding domain separate two cellular signal transduction pathways in drought- and low-temperature-responsive gene expression, respectively, in Arabidopsis / Q. Liu [et al.] // Plant Cell. - 1998. - V. 10. - P. 1391-1406.

6. Water deficits in wheat: fructan exohydrolase (1-FEH) mRNA expression and relationship to soluble carbohydrate concentrations in two varieties / J. Zhang [et al.] // New Phytologist. - 2009. - V. 181. - P. 843-850.

7. Welch B.L. The generalization of "Student's" problem when several different population variances are involved / B.L. Welch // Biometrika. - 1947. - V. 34 (1-2). - P. 28-35.

DOI 10.18699/GPB2020-123

\section{Значение биотехнологии в оздоровлении вегетативно размножаемого лука-шалота}

Щемелева Г.В., м.н.с., СИБНИИРС - филиал ИЦиГ СО РАН; аспирант, Новосибирский ГАУ, Новосибирск, Россия.

e-mail:shgv95@mail.ru

Рассмотрены биотехнологические методы в размножении лука-шалота представителя рода Alliuт. Выявлены преимущества над традиционными методами размножения. Описаны биотехнологические методы размножения, способы диагностики вирусов. Показана роль биотехнологических приемов для оздоровления вегетативно размножаемых растений. 